\title{
CRUISING SHIPS IN THE PORTS OF GDYNIA AND GDAŃSK
}

\author{
TAdeusz PalmowsKi, ${ }^{1}$ VALENTIN S. KORNEEVETS ${ }^{2}$ \\ ${ }^{1}$ Gdańsk University \\ Department Regional Development Geography \\ e-mail: geotpl@ug.edu.pl \\ ${ }^{2}$ Immanuel Kant Baltic Federal University \\ Institute of Recreation, Tourism and Sports \\ e-mail : IVKorneevets@kantiana.ru
}

\section{JEL CODE \\ KEYWORDS}

ABSTRACT

\section{$\mathrm{Z3}$}

cruising, Baltic maritime market, Gdańsk, Gdynia

The maritime tourist market is among the most attractive areas of business. The article identifies the transformation trends in Gdynia and Gdańsk cruising traffic in the years 2000-2017. In recent years, the Baltic has become one of the most vibrantly developing key cruising markets. Up to the year 2016, Gdynia enjoyed the greatest number of cruise ships calling Polish ports. Gdańsk took the lead in 2017. As the biggest cruise vessels continue to call Gdynia, whereas smaller ones call Gdańsk, the port of Gdynia continues to handle a considerably bigger number of passengers. The development of marine cruising tourism generates benefits for the ports themselves and the cities of Gdynia and Gdańsk, as well as the entire Pomeranian region.

\section{Introduction}

Tourism in recent years is gaining momentum and importance worldwide providing jobs and growing demand for the services. Jerzy Zaleski defined 'maritime tourism' as 'any form of tourist mobility expressed by sea voyages onboard cruise ships tailored for the purpose, or on board ships engaged in liner shipping offering trips in low season, leisure sailing which is not treated as sport but a form of spending leisure time, and passenger coastal shipping'. 
Cruise tourism, in turn, involves seagoing cruises usually on board ships specially built for this purpose. When calling ports, sightseeing usually takes the form of organised tours. This form of tourism involves visits on land to see the port, the city or even the entire coastal region. The sea voyage itself, that is the passage between particular ports, provides an opportunity to enjoy the attractions available thanks to the relevant infrastructure onboard of the cruise ships both in terms of cultural attractions and those aimed at passenger fitness.

This paper shows the direction of changes taking place in the ports of Gdynia and Gdańsk in cruising traffic in the years 2000-2007. Cruise tourism was studied by E. Chen (2012), R.K. Dowling (2006), S. Parker (2010), D. Ward (2006), C. Weeden, J. Lester and M. Thyne, (2011), and such Polish authors as M. Grzybowski (2005), W. Gaworecki (2007), J. Kizielewicz (2014, 2016), J.M. Miotke-Dzięgiel (2002), T. Palmowski (2011), M. Tarkowski and others (2016), D. Ccrić (2018), and J. Zaleski (1980).

\section{The world cruising market}

The maritime tourist market is among the most attractive areas of business. The world maritime tourism and cruising market, which in 1970 noted 0.5 million passengers expanded in 1998 to 9.5 million, in 2004 crossed the threshold of 13 million and in 2010 was assessed to be approximately 20 million. According to the estimates of Cruise Lines International Association (CLIA), over 25 million passengers embarked the vessels of shipowners of just this one association.

Americans on the Caribbean market dominate the industry providing services to $44 \%$ of tourists. Europe attracts merely one fifth of the global tourist demand for cruises. Passenger vessels operating in the region are becoming larger, more modern, and better equipped in all leisure related attractions. The dynamic growth of demand for this form of tourism resulted in plans for the construction of the next 70 larger cruise ships over the next 10 years. The largest cruise vessels take on board over 6.5 thousand passengers and 2 thousand crew members. These floating cities are both an attraction in seaports and a significant source of income for ports and the entire tourism industry in the region.

\section{The Baltic eruising market}

The Baltic market is among the biggest markets in terms of the potential development of passenger traffic. The demand for cruising services is of a seasonal nature. Thirty-seven major passenger fleet operators worldwide provide services on the Baltic Sea in 2018, offering cruises focusing on the cultural heritage of countries lying along the Baltic coast. Thirty-seven shipowners call 29 destinations in 10 countries.

The number of passengers cruising on the Baltic in 2017 exceeded 5,054 thousand. The most often called port was Copenhagen with 325 calls, St. Petersburg ranked second with 319 calls, Tallinn third - 311, Helsinki fourth - 266 and Stockholm fifth - 264.

St. Petersburg experienced the biggest hike of $17.3 \%$ in 2017 compared to 2016. Tallinn and Stockholm came second and third with an increase of $14.8 \%$. And $60.9 \%$ respectively, of the total 
number of 2,438 port calls of 1485 cruise ships, visited these five mentioned ports in 2017. The passenger volume on the Baltic in 2017 jumped by $16.6 \%$ compared to the year 2016. Over the period from 2000 to 2017 the number of guests on board cruise ships increased annually by $9.7 \%$ on average (from 1.1 million in 2000 to over 5 million in 2017). Forecasts indicate that the number of passengers visiting this water basin will grow by approximately $8 \%$ and reach the number of 5.5 million passengers in 2018.

The average passenger volume on board of a single ship in the years 2000-2017 numbered to 1301, whereas in 2007-2017 the number increased on average from 1,176 to 2,024 passengers on board of a single vessel (a $72.1 \%$ hike) as a result of shipowners introducing larger cruising vessels on the Baltic Sea.

The cruises organised in this region aim at familiarising guests with the cultural heritage of countries lying on the Baltic coast. ${ }^{1}$ Therefore, passenger cruising ships mainly call the most interesting locations, usually rooted in the Hanseatic League traditions; port towns offering sightseeing of historical sites, the architecture, museums; participation in cultural events, festivals and concerts. Baltic Europe also offers visitors the sites of beautiful, diversified landscapes. The port and the city infrastructure and suprastructure is well prepared to quickly and professionally handle cruising vessels. The Baltic water basin itself is perceived as a safe and clean sea, which in view of the complex geopolitical situation in the Mediterranean Sea boosts the attractiveness of the Baltic Sea.

The demand for cruising services is of a seasonal nature, where summertime provides the most favourable conditions for cruising, which corresponds to the holiday season. The effects of this seasonal demand are vivid on the Baltic Sea where passenger ships start calling Baltic ports from the end of April to the end of September. The greatest number of port calls are noted in June, July and August.

Passenger vessels operating on the Baltic are becoming bigger, more modern, and better equipped in all leisure related attractions (Table 1).

The authorities of Stockholm and Copenhagen initiated joint promotion of Baltic maritime tourism. Other cities followed. The cooperation of Baltic ports focuses on efforts to promote a common brand, raise awareness of tour operators of the positive image of Baltic ports, and increase the number of tourists in Baltic ports. This common offer supported by the EU funding is even addressed to Americans and Australians.

\section{Polish enviripnment}

Gaining of a competitive edge by Polish seaports over other ports in the Baltic Sea region is a challenge, particularly in terms of back-up facilities dedicated to handling passenger ships. Port authorities in Poland continue to moor cruise liners along quays located in unattractive port

${ }^{1}$ A cruise onboard of a cruise vessel is a voyage lasting not less than 60 hours, mainly for the pleasure of travelling by ship. This refers to passengers who buy out tickets and receive food and board. The voyage must include calls to at least two ports besides the port of embarking and disembarking. 
locations, berthing locations which do not contribute to port competitiveness on the Baltic market (Kizielewicz, 2014).

Passengers onboard cruising vessels, who travel on principle for leisure, are sensitive to their environment. The view of a picturesque old town or a modern metropolis from the ship encourages tourists to leave the ship and see the sites. However, if the ship is moored alongside bulk carriers, port cranes and warehouses or storage yards of scrap iron, the view will fail to attract visitors who often then resign from leaving the ship to see the region and enjoy the attractions onboard the passenger ship. The local tourism industry, the catering and souvenir industry suffer, similarly as the local self-governmental budget.

Ships calling the port of Gdynia are usually directed to the French Quay. The French Quay hosted transatlantic passenger vessels as early as in the thirties of the twentieth century. The Quay was put in order and the old Marine Station was transformed into the Emigration Museum, which today is a landmark of Gdynia. Unfortunately, the other shipside faces coal-handling operations, which leave coal dust on shiny-white passenger ship surfaces. The construction of a modern ferry terminal on the nearby Polish Quay will certainly improve the port's image in the eyes of visiting maritime tourists. The waterside access to the port is well adapted to handle passenger traffic with deep water quays, which can easily berth the largest passenger ships entering the Baltic Sea. These ships extend over 300 meters long and carry over 3,800 tourists and over 1.2 thousand crew members.

The situation in Gdańsk is similar. Cruising vessels in high season moor by quays dedicated to other purposes, mainly the handling of bulk cargo and storage of cars and containers.

Obrońców Westerplatte Quay is located close to the port entrance near Wisłoujście Fortress and the Westerplatte monument . Nearby is a haven for coastal passenger vessels offering transport to the old town centre of Gdańsk. Another quay, hosting small passenger ships, is the Capt. Ziółkowski Quay with a view of the historical lighthouse modelled on the lighthouse in Cleveland, Ohio. The third location is WOC II Quay easily reached within less than 20 minutes of passing the port entry. This is valued especially by tourists and tour operators who wish to take maximum advantage of berthing time for sightseeing.

Foreign tourists show growing interest in Gdańsk, therefore, the city authorities are preparing to construct a port terminal infrastructure dedicated to cruise ships for passenger traffic under the Central Port project to cater for larger cruise vessels.

Apart from the state and standard of the infrastructure, which may boost the number of cruise ship landings in Gdynia and Gdańsk, the weather and the tourist attractions of the landing play a significant role.

\section{Cruise ships in Gdańsk, in Gdynia}

Cruising in Polish shipping history, particularly in the period before the Second World War, has a rich tradition. Many objective factors in post-war Poland made access to passenger ship cruising difficult for Polish tourists. The radical change of the political situation after 1980 in Eastern 
Europe brought certain changes for Polish citizens and hopes of cruising on the Baltic Sea and enjoying other passenger ship voyages (Miotke-Dzięgiel, 2002).

Baltic cruise ships of major passenger shipping associations call the Polish ports of Gdynia and Gdańsk and sporadically Szczecin during their round voyages. The port and city of Gdynia, which was built before the Second World War, handled passenger traffic from the start, particularly transatlantic voyages.

The port is one of the targeted locations for cruise ships entering the Baltic. In effect, Gdynia hosted the biggest number of cruise ships visiting Poland in 2016. ${ }^{2}$ The number of these types of vessels in Gdańsk was lower, ranging from over ten to forty ships. In 2017, 64 passenger ships called Gdańsk. (Table 1). The present bathymetric conditions and length of quays clearly show that big passenger ships call Gdynia, while smaller passenger vessels call Gdańsk. In 2017, 64 cruise ships in Gdańsk carried nearly 32 thousand passengers, and 41 cruise ships in Gdynia had on board over 88 thousand guests. Thus, a distinct specialisation between Gdynia and Gdańsk appears for the next few years in the handling of passenger ship traffic.

The June 2017 a visit in Gdynia of one of the largest cruise ship worldwide was a highlighted event when $m / v$ Norwegian Getaway, a vessel 325 long (GT 145.655) with nearly four thousand passengers entered the port. The vessel $m / v$ Norwegian Getaway established at the time a historical record in terms of passenger ship gross tonnage entering the port. The record earlier belonged to $\mathrm{m} / \mathrm{v}$ Navigator of the Seas (GT 139.570), which moored in Gdynia port in 2007. In terms of hull length the previous record belonged to the 317 meters long $\mathrm{m} / \mathrm{v}$ Celebrity Eclipse. Thus, $\mathrm{m} / \mathrm{v}$ Norwegian Getaway broke a record in the cruise ship handling history of the port established ten years earlier.

$M / v$ Norwegian Getaway is equipped with everything that passengers need. Besides numerous restaurants, bars, a theatre and a gallery $\mathrm{m} / v$ Norwegian Getawy features, among others, a rope course and a rock climbing wall, a spider web enclosed climbing cage with slides and narrow planks projecting several meters beyond the ship sides for the brave. The ship also includes a medical centre with physicians and nurses on duty 24 hours a day.

The first cruise ship visiting the port in 2018 was the $\mathrm{m} / \mathrm{s}$ MSC Orchestra. The $294 \mathrm{~m}$ long and $32 \mathrm{~m}$ wide vessel takes on board 3 thousand passengers and 987 crew members. The cruise ship's godmother is Sophia Loren, a symbol of Italian elegance, and Ennio Morricone composed the music for the launching ceremony of $\mathrm{m} / \mathrm{s}$ MSC Orchestra.

The largest passenger ship calling the port of Gdynia in 2018 was the $316 \mathrm{~m}$ long $\mathrm{m} / \mathrm{v}$ Mein Schiff 1, which moored by the French Quay. This ship, built in 2018 in the Finnish shipyard in Turku, has a power saving and environmental friendly propulsion, which reduces emission of harmful substances by 30 percent compared to other ships of similar size. The vessel can accommodate nearly 2,900 passengers and a crew of 1,000. She started on her first voyage on May 3, 2018. On May 11, 2018, a spectacular christening ceremony of the vessel took place in Hamburg to give the TUI Cruises new vessel the name of Mein Schiff 1. During her maiden voyage, the ship entered

${ }^{2}$ Since the year 2001, Gdynia, as the only city in Poland, has a Passenger Ship Avenue, which commemorates the visits of the largest and the most beautiful cruise ships in the world. 
the port of Gdynia on May 21. During the 2018 season, the ship called Gdynia six times. The visits of such large cruise vessels like $m / v$ Mein Schiff 1 in Gdynia port are the best evidence of recognition and a symbol of appreciation of the port infrastructure and services provided by the port and cooperating companies.

Another spectacular event in the port of Gdynia, which took place on June 21, 2018, was the visit of the cruise ship $\mathrm{m} / \mathrm{v} /$ Queen Elizabeth, which is the youngest vessel of the legendary liner Cunnard, launched in 2010 and christened by the monarch Elizabeth II. The 294 long and $32 \mathrm{~m}$ wide $m / v$ Queen Elizabeth can accommodate nearly 2,100 passengers and a 940-strong crew catering for their needs.

Up to 2017, the average number of passenger ships calling the port of Gdańsk read 64. For the 2018 season, Gdańsk received pre-arrival notification of 74 cruise ships. The biggest vessel of this season is Marina flying the Flag of Marshall Islands. The $239 \mathrm{~m}$ long vessel called Gdańsk on June 20. Pre-arrival notification included the Viking Cruises fleet and all four vessels are to appear in the port of Gdańsk. The newest vessel called Viking Sun was put in service at the end of 2017. The cruise passenger season in Gdańsk will end with the visit of the $176 \mathrm{~m}$ long Marco Polo.

Table 1. Cruise ship traffic to Gdańsk and Gdynia in the years 2000-2018

\begin{tabular}{ccccc}
\hline \multirow{2}{*}{ Year } & \multicolumn{3}{c}{ Gdańsk } & \multicolumn{3}{c}{ Gdynia } \\
\cline { 2 - 5 } & number of calls & number of passengers & number of calls & number of passengers \\
\hline 2000 & 14 & 3,643 & 72 & 57,410 \\
2001 & 17 & 3,486 & 74 & 56,460 \\
2002 & 14 & 3,609 & 53 & 26,660 \\
2004 & 7 & 3,367 & 95 & 58,411 \\
2005 & 28 & 7,359 & 82 & 72,977 \\
2006 & 32 & 8,353 & 94 & 88,723 \\
2007 & 29 & 9,703 & 89 & 94,135 \\
2008 & 39 & 12,193 & 87 & 89,088 \\
2009 & 36 & 13,276 & 89 & 123,521 \\
2010 & 40 & 16,753 & 96 & 134,884 \\
2011 & 26 & 8,378 & 85 & 125,005 \\
2012 & 21 & 6,787 & 56 & 78,418 \\
2013 & 29 & 8,294 & 69 & 103,623 \\
2914 & 30 & 10,508 & 57 & 80,470 \\
2015 & 38 & 14,974 & 50 & 91,971 \\
2016 & 25 & 10,814 & 45 & 71,923 \\
2017 & 32 & 12,566 & 50 & 81,833 \\
2018 & 64 & 31,790 & 41 & 88,616 \\
\hline
\end{tabular}

${ }^{*}$ Pre-arrival notification.

Source: own studies based on data of Gdańsk and Gdynia ports. 
Ships calling Gdynia and Gdańsk usually berth for one day, which means for less than 20 hours. Only $4 \%$ of the vessels stay two days or more. ${ }^{3}$ During the stay in port, passengers can choose from a wide range of coach trips and visit the TriCity (old Hanseatic Gdańsk, the Sopot health resort and the dynamically developing Gdynia). The sightseeing tours usually include the old city in Gdańsk, the Oliwa Cathedral, and Gdańsk Shipyard where the Solidarity movement initiated democratic transformations in Eastern Europe. Trips to the Teutonic Castle in Malbork are also popular as are the ethnographic and environmental trips to the Kashubia area.

Various route options and good logistic planning of tour operators allow tourists to reach interesting cultural and natural environment locations distanced several tens of kilometres from the port.

It is assumed that a tourist spends on average 100-125 euro in TriCity. We can estimate that in 2017 guests coming by sea spent 16.6 million euro. As Gdańsk is a world centre of amber processing and amber trade and both Gdańsk and the castle in Malbork have museums presenting natural amber and pieces of art made from the material, many tourists acquire various amber products in silver and gold produced by Gdańsk craftsmen. The tourist visits also bring benefits to owners of coffee bars, restaurants etc. Nearly half of the guests are American tourists, who together with Spaniards are most appt to shop. Prudent German tourists dominate at the other end of this shopping spree. The development of this form of maritime tourism multiples the income of tour operators, transport companies, restaurants and artisans processing amber.

What hinders the development of this form of maritime tourism in Poland? A lack of close cooperation of ports, self-governmental authorities, shipowners and travel bureaus obstruct the industry's development. High port fees collected from ships calling Polish ports do not encourage organisers of tourist cruises to include Polish ports in their itineraries. Provisions of law impose the duty of as many as four assisting tugs for the entry of a passenger vessel to port. The prices of daylong excursions offered to passengers arriving in Gdynia are higher than in other foreign ports (Somorowska, 2005).

\section{Promoting TriCity and Pomerania}

Not all ships cruising on the Baltic Sea enter Gdynia and Gdańsk. The development of international promotion and offers of Polish cities and travel bureaus are required to improve the situation. It is indispensable for all companies and institutions in the region involved in promotion, catering and accommodation, running coach transport services and tourism business companies to reach an understanding and develop common measures for the development of maritime tourism.

To attract visitors and promote our country and region the ports of Gdynia and Gdańsk jointly participate in the Seatrade Cruise Global Fairs in Fort Lauderdale in Florida. The Fair is the greatest meeting of cruise sector stakeholders. The events have been held for over 30 years. The Fair

\footnotetext{
${ }^{3}$ In Sankt Petersburg, $77 \%$ of the overall stay time in port lasted more than one day, in Copenhagen $25 \%$.
} 
location is not a random choice. The Caribbean region generates the greatest number of cruise ships in the world. The head offices of the biggest shipowners are seated in this location.

During the Seatrade Europe 2017 Fair in Hamburg, where the latest market trends in maritime tourism and green technologies are presented, as well as the impact of the general geopolitical situation on this market, the representatives of the port of Gdynia made efforts to attract cruising liners and new clients.

For several years now, the port of Gdańsk has been involved in international organisations concentrating on the tourist travel industry related issues. One of such organisations is Cruise Europe, whish associates over 100 European ports in four regions of the continent: Iceland and Norway, the Baltic Sea, Great Britain and Ireland, and the western coast of Europe. In 2011, the port of Gdańsk joined the Cruise Baltic Organisation, which associates 29 ports and cities in nine countries of Baltic Europe. The organisation popularises the Baltic Sea Region, its attractions, beauty and tourist assets among tourists, shipowners and tour operators.

Ports work for the country. Similarly as growing cargo handling volumes drive the economy, developing passenger ship connections contribute to blooming tourism. New connections bring benefits not only to ports but also to the cities of Gdynia and Gdańsk and the entire Pomerania. The importance of Poland on the world cruising map continues to exhibit growth. This voyage direction is becoming more attractive for tourists. These trends should be well used. Comprehensive servicing of all kinds of passenger ships which enter the Baltic Sea are the objective of both Gdańsk and Gdynia ports, which impel efforts to meet the expectations of shipowners, who choose our ports. A growth in the number of calling passenger ships is hoped for, which should be reflected in the number of visiting tourists.

\section{Conclusions}

The maritime tourist market is among the most attractive areas of business. In recent years, the Baltic Sea has become one of the best developing cruising markets. The cruising sector fits well into the European Union integration process.

Port Gdynia ranks as the most important and the safest Polish passenger port hosting for many years cruise ships on the Baltic Sea. Passenger ships are becoming a landmark, an actual element of the Gdańsk port landscape. More ships come every year.

In 2016, Gdynia hosted the biggest number of cruise ships visiting Poland. Contemporary big cruising ships call Gdynia, whereas smaller passenger vessels visit the port of Gdańsk. In 2017, 64 cruise ships brought nearly 32 thousand passengers to Gdańsk, and 41 cruise ships which called Gdynia had over 88 thousand guests on board.

The cooperation of Polish ports with shipowners and cruise ship operators is already showing expected effects with the growing number of vessels calling Polish ports and the growing participation of Poles in this form of maritime tourism.

The entry of larger cruise ships to Baltic waters stimulates regular port development, including the construction of bigger and deeper berths, modern passenger terminal, facilities for waste 
collection, etc. It also affects the development of local road and rail infrastructure and in some cases flight infrastructure.

Passenger connections contribute to the development of tourism and bring benefits not only to ports but also to the cities of Gdynia and Gdańsk and the entire Pomerania. The development of marine cruising generates a significant income in the entire Baltic Europe. Cautious estimates exceed 500 million euro.

\section{Referenences}

Ccrić, D. (2018). Cruise Tourism: From Regional Saturation Towards Global Dynamic Equilibrium. In: D.K Müller, M. Więckowski (eds.), Tourism in Transitions, geographies of Tourism and global Change. Springer International Publishing AG.

Chen, E. (2012). Cruise Industry Trends to 2025. Ocean Shipping Consultants, Royal Haskoning DHV UK Ltd.

Cruise Baltic Status Report, Final, January (2007).

Cruise Baltic Market Review (2018).

Cruise Tourism - Current Situation and Trends (2010). Madrid: World Tourism Organization UNWTO.

Dowling, R.K. (ed.) (2006). Cruise Ship Tourism. Cambridge: CAB International Publishing.

Grzybowski, M. (2005). Tourism. The Baltic Offensive. The Warsaw Voice, 6 February, 34.

Grzybowski, M., Piotrowska, J. (2010). Wycieczkowce w polskich portach. Nadmorski Przeglad Gospodarczy, 5 (101).

Kizielewicz, J., Skrzeszewska, K. (2014). Inwestycje infrastrukturalne w porcie morskim w Gdyni na rzecz rozwoju turystyki statkiem wycieczkowym. Zeszyty Naukowe Uniwersytetu Szczecińskiego, 843. Problemy Transportu i Logistyki, 28, 77-94.

Kizielewicz, J. (2014). Konkurencyjność polskich portów morskich w zakresie obsługi statków wycieczkowych w basenie Morza Bałtyckiego. Przedsiębiorczość i Zarzadzanie, 15 (4/3), 79-90.

Kizielewicz, J. (2014). Morskie terminale dedykowane obsłudze pasażerskich statków wycieczkowych - przykłady dobrych praktyk. Logistyka, 6, 785-794.

Kizielewicz, J. (2016). Konsumpcja podróżujących morskimi statkami wycieczkowymi w nadmorskich obszarach recepcji turystycznej. Gdynia: Wydawnictwo Akademii Morskiej w Gdyni.

Miotke-Dzięgiel, J.M. (2002). Turystyka morska. Gdańsk: Wydawnictwo Uniwersytetu Gdańskiego.

Palmowski, T. (2011). Battycki cruising, Prace Komisji Geografii Komunikacji PTG. Warszawa: Komisja Geografii Komunikacji PTG w Warszawie, Instytut Geografii i Przestrzennego Zagospodarowania im. Stanisława Leszczyckiego PAN w Warszawie, Volume XVIII.

Papathanassis, A., Lukovic, T., Vogel, T. (eds.) (2012). Cruise Tourism and Society: A Socio-economic perspective. Berlin Heidelberger: Springer-Verlag.

Parker, S. (2010). Baltic tackles growth issues. Cruise Business Review, 1.

Somorowska, A. (2005). Szanse i Bariery turystyki morskiej. Morze i Handel, 21 (664).

Tarkowski, M., Palmowski, T., Kopeć, K., Wendt, J.A. (2016). Gdynia w Unii Europejskiej. Konkurencyjność gospodarki. Gdańsk-Pelplin: Wydawnictwo Bernardinum.

Ward, D. (2006). Complete Guide to Cruising \& Cruise Ships. Singapore: Berlitz.

Weeden, C., Lester, J., Thyne, M. (2011). Cruise tourism: Emerging issues and implications for a maturing industry. Journal of Hospitality and Tourism Management, 1 (18).

Zaleski, J., Wojewódka, Cz. (1977). Europa Baltycka. Zarys monografii gospodarczej. Wrocław: Ossolineum.

Zaleski, J. (1980). Problemy rozwoju turystyki morskiej i nadmorskiej w świetle współczesnych tendencji badawczych. In: Turystyka i rekreacja nadmorska problemy teorii i praktyki (pp. 29-41). Gdańsk: Wyższa Szkoła Wychowania Fizycznego im. Jędrzeja Śniadeckiego. 


\section{CRUISING W PORTACH GDYNI I GDAŃSKA}

SŁOWA KLUCZOWE

STRESZCZENIE cruising, morski rynek bałtycki, Gdańsk, Gdynia

Morski rynek turystyczny należy do jednego z najbardziej atrakcyjnych obszarów działalności. Celem artykułu jest wskazanie kierunków przemian w jakie zachodziły w portach Gdyni i Gdańska w ruchu cruisingowym w latach 2000-2017. W ostatnich latach Bałtyk stał się jednym najszybciej rozwijających się głównych rynków żeglugi wycieczkowej. Do roku 2016 liczba zawijających statków tego typu do Gdyni była największa spośród polskich portów. Od 2017 roku na czoło wysunął się Gdańsk. Ze względu na to że duże cruisery zawijają do Gdyni, a mniejsze do Gdańska znacznie więcej pasażerów wycieczkowców nadal obsługuje port w Gdyni. Rozwój morskiej turystyki cruisingowej przynosi wymierne korzyści nie tylko portom, ale i miastom Gdynia, Gdańsk i całemu Pomorzu. 